\title{
BIBLIOMETRIC ANALYSIS OF THE JOURNAL OF CIVIL ENGINEERING AND MANAGEMENT BETWEEN 2008 AND 2018
}

\author{
Dejian YU®1 ${ }^{1}$, Zeshui XU (1) 2,3*, Jurgita ANTUCHEVIČIENE் 4 \\ ${ }^{1}$ Business School, Nanjing Audit University, Nanjing 211815, China \\ ${ }^{2}$ Business School, State Key Laboratory of Hydraulics and Mountain River Engineering, \\ Sichuan University, Chengdu 610064, China \\ ${ }^{3}$ School of Computer and Software, Nanjing University of Information Science \\ and Technology, Nanjing 210044, China \\ ${ }^{4}$ Department of Construction Management and Real Estate, Vilnius Gediminas Technical University, \\ Sauletekio al. 11, LT-1022, Vilnius, Lithuania
}

Received 25 March 2019; accepted 01 April 2019

\begin{abstract}
The Journal of Civil Engineering and Management (JCEM) is a prestigious international journal in the field of engineering. This paper uses the method of bibliometric to study the status and development trends of the journal. Information was collected from the Science Citation Index (SCI) database. Firstly, the general citation structure and basic characteristics of the JCEM journal are investigated. Then, the most influential institutions, countries as well as their networks of cooperation are identified. Finally, the main research topics of the JCEM journal are explored by using the frequently used keywords. This paper explores the internal structure and development trend of the JCEM journal, which not only provides an important reference for the future development of this journal, but also provides an effective analysis method for the future evaluation of journals.
\end{abstract}

Keywords: bibliometric analysis, citation structure, Web of Science, journal, VOSviewer, CiteSpace.

\section{Introduction}

The Journal of Civil Engineering and Management (JCEM) is a prestigious journal in the field of engineering published 8 times a year by Vilnius Gediminas Technical University (VGTU) Press. It was created by Prof. Edmundas Kazimieras Zavadskas from Lithuanian Academy of Sciences and VGTU. According to the Journal Citation Reports of Clarivate Analytics Web of Science, the latest impact of the JCEM journal is 1.66 and it ranks 55th out of 128 "engineering, civil" categorized journals. Today, it is officially encouraged journal of the International Council for Research and Innovation in Building and Construction (CIB) and is one of the outstanding journals in the research domain of civil engineering. So far, the JCEM has published more than 1000 papers in the field of civil engineering. Therefore, it is necessary to conduct a comprehensive analysis and summary of the journal from the perspective of bibliometric.

Bibliometrics is a discipline that is produced by the extensive intersection and combination of philology, in- formation science, mathematics, and statistics $(\mathrm{He}, \mathrm{Wu}$, Yu, \& Merigó, 2017; Yu, Xu, \& Wang, 2018). It is also a relatively mature and important branch of intelligence science (Pritchard, 1969; Borgman \& Furner, 2002; White, 2018). At present, bibliometrics has been widely used to many fields, such as computer science (Hao, Chen, $\mathrm{Li}, \&$ Yan, 2018; Ortega, 2019), engineering (Maditati, Munim, Schramm, \& Kummer 2018; Wu et al., 2018), sustainable energy (Yu \& Xu, 2017; Hache \& Palle, 2019) and economics (Ertz \& Leblanc-Proulx, 2018; Cui \& Zhang, 2018). Using the methods and techniques of bibliometrics to comprehensively analyze all the papers in a specified journal to reveal its internal structure and development trend is one of the research hotspots in the field of bibliometrics. Recently, Laengle et al. (2017) presented a bibliometric analysis of the European Journal of Operational Research journal to celebrate its 40th anniversary. Martínez-López, Merigó, Valenzuela-Fernández, and Nicolás (2018) explored the leading trends of the European Jour-

*Corresponding author. E-mail: xuzeshui@263.net 
nal of Marketing during the past 50 years by using bibliometric indicators. Yu, Xu, Kao, and Lin (2018) studied the IEEE Transactions on Fuzzy Systems publications and revealed the important factors that affect the development of this journal. Yu, Xu, and Fujita (2019) examined the inner structure and the evolution of the Applied Intelligence journal based on bibliometric methods. Using some visualization tools, such as VOSviewer and CiteSpace, many bibliometric research results have been achieved for some journals (Yu, Xu, Pedrycz, \& Wang, 2017; Tur-Porcar, Mas-Tur, Merigó, Roig-Tierno, \& Watt, 2018; Wang et al., 2018).

The existing research results show that the bibliometric analysis of a journal can find out a lot of valuable information, and this kind of study is of great significance. However, up to now, there is no research for the JCEM journal based on the bibliometric methods. The rest of this paper is organized as follows: Section 1 studies the general citation structure and basic characteristics of the JCEM journal. Section 2 illustrates the different kinds of networks of cooperation and explores the research topics of this journal. The concluding remarks are presented in last Section.

\section{General analysis of the JCEM publications}

The information analyzed in this study is 821 JCEM publications (only articles and reviews) which are indexed in the Science Citation Index (SCI) database dating between 2008 and 2018 and is retrieved in January $25^{\text {th }}, 2019$.

\subsection{Who is paying attention to the JCEM}

The JCEM is a highly internationalized academic journal in the field of civil engineering, which has attracted extensive attention from experts and scholars all over the world. This section focuses on the question of which journals, countries/territories, institutions, authors and WOS categories are particularly concerned about the JCEM? Research findings are presented in Table 1.

As far as the journal is concerned, the JCEM itself ranked first with 468 publications. This means that there are one or more JCEM papers in the references of these 468 publications. Following are Construction and Building Materials with 207 and Procedia Engineering with 142 papers cited the JCEM publications, respectively. Two other journals with more than 100 papers cited the JCEM publications are Automation in Construction and Technological and Economic Development of Economy. In terms of the countries/territories, Lithuania (782) and China (766) ranked first and second positions, respectively. Poland, Iran and USA have 372, 361 and 329 publications cited the JCEM publications and ranked in the third to fifth palaces. Australia, Malaysia, England, Czech Republic and Spain complete the top 10 positions.

VGTU from Lithuania has 718 papers cited the JCEM publications, and it is far ahead of Brno University of Technology from Czech Republic and Islamic Azad University from Iran which are ranked second and third posi- tions, respectively. The founder \& Editor-in-Chief of the JCEM, prof. E. K. Zavadskas from VGTU, has 203 papers cited the JCEM publications. The followed authors are Z. Turskis and J. Antuchevičiene, both from VGTU. The fourth and fifth authors are M. Z. Jumaat from University of Malaya and Z. Kala from Brno University of Technology, respectively. The WOS category of Engineering Civil is the most popular area of the JCEM. As shown in Table 1, there are 2014 papers from this area cited the JCEM publications.

\subsection{Characteristics of the JCEM publications}

A comprehensive analysis from 2008 to 2018 was designed to evaluate the evolution of the characteristics of the JCEM Journal. The changes in characteristics often reflect some significant developing processes of the journal. To show the trajectory of the development of the JCEM journal, this study presents three characteristics of the JCEM journal, (1) the number of pages, (2) the number of references and (3) the number of authors, and shown in Table 2.

According to the number of pages, at a general level, we can easily get that $52.86 \%$ papers are equal to or less than 10 pages. There is clear evidence of an increase in the average number of pages of the JCEM papers. To deepen the result, we focus on the table throughout years and divide the whole period into three different stages. It is clear that the papers with 14 or more pages rose most rapidly. During the first period (2008-2010), they only accounted for $2.84 \%$, however, this share climb to 17.80 in the latest stage. Contrary to this, the papers with 7 or less pages decreased mostly from $29.79 \%$ to $3.11 \%$.

Another interesting characteristic related to the papers in the JCEM journal is the number of references. As we can see, the number of references cited by the JCEM publications concentrate on 21-40, which accounts $52.62 \%$ of the total. Among these, there are the publications with 21-30 references (31.91\%) and those with 31-40 references $(20.71 \%)$. The share of papers with more than 30 references increased significantly and there is an upward trend. Furthermore, this analysis provides the fact that the share of papers with less than 20 references has been reduced, especially the papers citing equal or less than 10 references have almost disappeared in the JCEM journal.

Regarding the number of authors which refer to the degree of co-authorship (Köseoglu, Okumus, Putra, Yildiz, \& Dogan, 2018; Silva, Schulz, \& Noyons, 2019), the most popular pattern of co-authorship is 2 or 3 authors (58.59\%). Furthermore, a substantial increase occurred in the average number of authors during the whole period. The publications with more than 3 or more authors occupied more proportion, whereas those with 1-2 authors decreased. Especially the publications with 4 authors increased approximately $9 \%$ while the publications written by single author declined most from $19.86 \%$ to $6.21 \%$. A probable reason is that with the development of the JCEM journal, the issues in this field have been becoming more complicated and diversified, which need more researchers to work out together. 
Table 1. Numbers of Sources citing the JCEM articles

\begin{tabular}{|c|c|c|c|c|c|c|c|c|c|c|}
\hline Rank & Journals & $\mathrm{TP}$ & $\begin{array}{l}\text { Country/ } \\
\text { Territory }\end{array}$ & $\mathrm{TP}$ & Institution & $\mathrm{TP}$ & Authors & $\mathrm{TP}$ & Categories & $\mathrm{TP}$ \\
\hline 1 & $\begin{array}{l}\text { Journal of Civil } \\
\text { Engineering and } \\
\text { Management }\end{array}$ & 468 & Lithuania & 782 & VGTU & 718 & Zavadskas E. K. & 203 & $\begin{array}{l}\text { Engineering } \\
\text { Civil }\end{array}$ & 2014 \\
\hline 2 & $\begin{array}{l}\text { Construction and } \\
\text { Building Materials }\end{array}$ & 207 & China & 766 & $\begin{array}{l}\text { Brno University } \\
\text { of Technology }\end{array}$ & 128 & Turskis Z. & 85 & $\begin{array}{l}\text { Construction } \\
\text { Building } \\
\text { Technology }\end{array}$ & 1106 \\
\hline 3 & $\begin{array}{l}\text { Procedia } \\
\text { Engineering }\end{array}$ & 142 & Poland & 372 & $\begin{array}{l}\text { Islamic Azad } \\
\text { University }\end{array}$ & 121 & Antucheviciene J. & 49 & $\begin{array}{l}\text { Materials Science } \\
\text { Multidisciplinary }\end{array}$ & 538 \\
\hline 4 & $\begin{array}{l}\text { Automation in } \\
\text { Construction }\end{array}$ & 108 & Iran & 361 & $\begin{array}{l}\text { Wroclaw } \\
\text { University } \\
\text { of Science } \\
\text { Technology }\end{array}$ & 101 & Jumaat M. Z. & 45 & $\begin{array}{l}\text { Engineering } \\
\text { Industrial }\end{array}$ & 277 \\
\hline 5 & $\begin{array}{l}\text { Technological } \\
\text { and Economic } \\
\text { Development of } \\
\text { Economy }\end{array}$ & 100 & USA & 329 & $\begin{array}{l}\text { University of } \\
\text { Malaya }\end{array}$ & 99 & Kala Z. & 45 & Management & 264 \\
\hline 6 & Sustainability & 88 & Australia & 272 & $\begin{array}{l}\text { Hong Kong } \\
\text { Polytechnic } \\
\text { University }\end{array}$ & 98 & Tamosaitiene J. & 38 & Economics & 260 \\
\hline 7 & $\begin{array}{l}\text { Journal of } \\
\text { Construction } \\
\text { Engineering and } \\
\text { Management }\end{array}$ & 72 & Malaysia & 211 & $\begin{array}{l}\text { Kaunas } \\
\text { University of } \\
\text { Technology }\end{array}$ & 76 & Sivilevicius H. & 34 & $\begin{array}{l}\text { Engineering } \\
\text { Multidisciplinary }\end{array}$ & 250 \\
\hline 8 & $\begin{array}{l}\text { Baltic Journal of } \\
\text { Road and Bridge } \\
\text { Engineering }\end{array}$ & 71 & England & 184 & $\begin{array}{l}\text { Tongji } \\
\text { University }\end{array}$ & 58 & Kaklauskas A. & 29 & $\begin{array}{l}\text { Engineering } \\
\text { Mechanical }\end{array}$ & 246 \\
\hline 9 & $\begin{array}{l}\text { Modern Building } \\
\text { Materials Structures } \\
\text { and Techniques }\end{array}$ & 61 & Czech Republic & 168 & $\begin{array}{l}\text { Malaysian } \\
\text { University of } \\
\text { Technology }\end{array}$ & 53 & Skitmore M. & 29 & $\begin{array}{l}\text { Environmental } \\
\text { Sciences }\end{array}$ & 223 \\
\hline 10 & $\begin{array}{l}\text { Journal of } \\
\text { Management in } \\
\text { Engineering }\end{array}$ & 59 & Spain & 166 & $\begin{array}{l}\text { Queensland } \\
\text { University of } \\
\text { Technology }\end{array}$ & 51 & Kaklauskas G. & 28 & $\begin{array}{l}\text { Green } \\
\text { Sustainable } \\
\text { Science } \\
\text { Technology }\end{array}$ & 220 \\
\hline 11 & $\begin{array}{l}\text { Archives of Civil } \\
\text { and Mechanical } \\
\text { Engineering }\end{array}$ & 56 & Turkey & 164 & $\begin{array}{l}\text { Chinese } \\
\text { Academy of } \\
\text { Sciences }\end{array}$ & 50 & Sadowski L. & 28 & Energy Fuels & 197 \\
\hline 12 & $\begin{array}{l}\text { Journal of Cleaner } \\
\text { Production }\end{array}$ & 55 & Taiwan & 157 & $\begin{array}{l}\text { University of } \\
\text { New South } \\
\text { Wales Sydney }\end{array}$ & 49 & Adeli H. & 27 & Mechanics & 149 \\
\hline 13 & $\begin{array}{l}\text { Engineering } \\
\text { Structures }\end{array}$ & 52 & South Korea & 131 & $\begin{array}{l}\text { Poznan } \\
\text { University of } \\
\text { Technology }\end{array}$ & 48 & Chan A. P. C. & 27 & $\begin{array}{l}\text { Computer } \\
\text { Science } \\
\text { Interdisciplinary } \\
\text { Applications }\end{array}$ & 138 \\
\hline 14 & $\begin{array}{l}\text { KSCE Journal of } \\
\text { Civil Engineering }\end{array}$ & 47 & Italy & 129 & $\begin{array}{l}\text { Indian Institute } \\
\text { of Technology } \\
\text { System }\end{array}$ & 44 & Valivonis J. & 26 & $\begin{array}{l}\text { Computer } \\
\text { Science Artificial } \\
\text { Intelligence }\end{array}$ & 131 \\
\hline 15 & Transport & 47 & India & 125 & $\begin{array}{l}\text { Amirkabir } \\
\text { University of } \\
\text { Technology }\end{array}$ & 43 & $\begin{array}{l}\text { Yazdani- } \\
\text { Chamzini A. }\end{array}$ & 26 & $\begin{array}{l}\text { Engineering } \\
\text { Environmental }\end{array}$ & 125 \\
\hline
\end{tabular}


Table 2. Characteristics of the JCEM publications

\begin{tabular}{|c|c|c|c|c|}
\hline \multirow[b]{2}{*}{ Characteristics } & \multirow{2}{*}{$\begin{array}{c}\text { Total } \\
(\mathrm{n}=821) \%\end{array}$} & \multicolumn{3}{|c|}{ Time Period } \\
\hline & & $\begin{array}{c}2008-2010 \\
\left(\mathrm{n}_{1}=141\right) \%\end{array}$ & $\begin{array}{c}2011-2014 \\
\left(\mathrm{n}_{2}=326\right) \%\end{array}$ & $\begin{array}{c}2015-2018 \\
\left(\mathrm{n}_{3}=354\right) \%\end{array}$ \\
\hline \multicolumn{5}{|c|}{ Number of pages } \\
\hline 7 or less & 10.48 & 29.79 & 10.12 & 3.11 \\
\hline 8 & 12.30 & 19.15 & 9.20 & 12.43 \\
\hline 9 & 15.10 & 15.60 & 15.03 & 14.97 \\
\hline 10 & 14.98 & 12.06 & 17.79 & 13.56 \\
\hline 11 & 13.89 & 8.51 & 15.95 & 14.12 \\
\hline 12 & 11.57 & 9.22 & 9.82 & 14.12 \\
\hline 13 & 8.40 & 2.84 & 9.20 & 9.89 \\
\hline 14 or above & 13.28 & 2.84 & 12.88 & 17.80 \\
\hline \multicolumn{5}{|c|}{ Number of references } \\
\hline 10 or less & 0.73 & 3.55 & 0.00 & 0.28 \\
\hline $11 \sim 20$ & 18.03 & 32.62 & 17.79 & 12.43 \\
\hline $21 \sim 30$ & 31.91 & 32.62 & 31.29 & 32.20 \\
\hline $31 \sim 40$ & 20.71 & 15.60 & 21.17 & 22.32 \\
\hline $41 \sim 50$ & 13.89 & 10.64 & 14.42 & 14.69 \\
\hline $51 \sim 60$ & 7.43 & 2.84 & 8.59 & 8.19 \\
\hline $61 \sim 70$ & 3.17 & 0.71 & 3.07 & 4.24 \\
\hline 71 or more & 4.14 & 1.42 & 3.68 & 5.65 \\
\hline \multicolumn{5}{|c|}{ Number of authors } \\
\hline One & 9.74 & 19.86 & 9.20 & 6.21 \\
\hline Two & 27.41 & 32.62 & 28.83 & 24.01 \\
\hline Three & 31.18 & 28.37 & 31.90 & 31.64 \\
\hline Four & 17.66 & 12.06 & 15.95 & 21.47 \\
\hline Five & 10.60 & 6.38 & 10.74 & 12.15 \\
\hline Six & 2.44 & 0.00 & 3.37 & 2.54 \\
\hline Seven or more & 0.97 & 0.71 & 0.00 & 1.98 \\
\hline
\end{tabular}

\subsection{Most productive countries/territories}

Table 3 demonstrates ten most productive countries/ territories in three different stages. They are sorted in a decreasing manner according to their total publications (TP). Note that several other indicators are considered including the total citations (TC) and h-index.

Lithuania clearly dominates the list with more than twice the number of papers of Poland (85), which is in the second place. Besides, Lithuania is also far away from the other countries in terms of the TC and h-index. There is no doubt that Lithuania plays the most significant role in the JCEM journal with both the most publications and influence.

Next, let us analyze the publication of countries through the different stages. In general, the number of papers is emerging strongly. Although, compared with Stage 2, the TC and h-index in Stage 3 decreased, it does not affect this emerging trend. It must be highlighted that papers need several years to be cited after their publications. So it is understandable that publications in current years received a low citation which also results a low h-index.
During every period of the journal, the Lithuania is the most productive country in the journal. However, China has made a great progress over time. Moreover, a more dramatic improvement happened in the third stage, China replaced Poland becoming the second productive country in the list. It shows that China is paying a tremendous attention on the JCEM and contributes a lot to the development of this journal in current years. However, Malaysia, Algeria and Czech Republic, which was the top 10 at first two stages, now they are out of the list.

\subsection{Top H-index countries/territories}

Lithuania, Poland and China remain in the top three based on the h-index, in line with the ranking of published numbers. To deepen the results, let us take a threshold analysis. The number of publications with more than 100 citations is three in total. Those papers are the most representative and influential in the JCEM journal. Note that these three papers are all come from Lithuania. Besides, the papers with more than 50 citations are counted as six, and two of them published by Lithuania, while Poland, China, Turkey and Australia each have one. 
Table 3. Most productive influential countries/territories in three different stages

\begin{tabular}{|c|c|c|c|c|c|c|c|c|c|c|c|c|}
\hline \multirow[b]{2}{*}{ Rank } & \multicolumn{4}{|c|}{ 2015-2018 } & \multicolumn{4}{|c|}{ 2011-2014 } & \multicolumn{4}{|c|}{ 2008-2010 } \\
\hline & $\begin{array}{l}\text { Country/ } \\
\text { Territory }\end{array}$ & $\mathrm{H}$ & $\mathrm{TP}$ & TC & $\begin{array}{l}\text { Country/ } \\
\text { Territory }\end{array}$ & $\mathrm{H}$ & $\mathrm{TP}$ & TC & $\begin{array}{l}\text { Country/ } \\
\text { Territory }\end{array}$ & $\mathrm{H}$ & $\mathrm{TP}$ & TC \\
\hline 1 & Lithuania & 8 & 58 & 222 & Lithuania & 15 & 78 & 703 & Lithuania & 18 & 54 & 1336 \\
\hline 2 & China & 5 & 53 & 109 & Poland & 12 & 37 & 375 & Poland & 10 & 17 & 300 \\
\hline 3 & USA & 7 & 44 & 164 & Taiwan & 9 & 32 & 236 & Turkey & 8 & 8 & 194 \\
\hline 4 & Poland & 6 & 31 & 128 & USA & 10 & 30 & 278 & USA & 4 & 8 & 96 \\
\hline 5 & South Korea & 4 & 31 & 78 & Malaysia & 8 & 27 & 206 & China & 7 & 7 & 187 \\
\hline 6 & Iran & 7 & 30 & 113 & Iran & 10 & 24 & 290 & Taiwan & 5 & 7 & 56 \\
\hline 7 & Taiwan & 6 & 28 & 105 & China & 9 & 24 & 204 & England & 4 & 5 & 78 \\
\hline 8 & Turkey & 6 & 26 & 123 & Turkey & 9 & 21 & 200 & Algeria & 4 & 4 & 78 \\
\hline 9 & Portugal & 5 & 15 & 66 & England & 5 & 11 & 63 & CzechRepublic & 3 & 4 & 154 \\
\hline 10 & Spain & 6 & 14 & 78 & South Korea & 4 & 11 & 44 & South Korea & 3 & 4 & 48 \\
\hline
\end{tabular}

Table 4. TOP H-index countries/territories

\begin{tabular}{|l|c|c|c|c|c|c|c|c|c|c|}
\hline Country/Territory & $\mathrm{H}$ & $\mathrm{TP}$ & $\mathrm{TC}$ & $\mathrm{TC} / \mathrm{TP}$ & $\geq 100$ & $\geq 50$ & $\geq 20$ & $\geq 10$ & $\geq 1$ & $\mathrm{CR}$ \\
\hline Lithuania & 23 & 190 & 2261 & 12 & 3 & 2 & 25 & 37 & 100 & $47.37 \%$ \\
\hline Poland & 16 & 85 & 803 & 9 & 0 & 1 & 11 & 15 & 47 & $36.47 \%$ \\
\hline China & 12 & 84 & 500 & 6 & 0 & 1 & 6 & 10 & 45 & $63.10 \%$ \\
\hline USA & 12 & 82 & 538 & 7 & 0 & 0 & 7 & 11 & 52 & $71.95 \%$ \\
\hline Iran & 12 & 56 & 425 & 8 & 0 & 0 & 4 & 10 & 36 & $66.07 \%$ \\
\hline Turkey & 12 & 55 & 517 & 9 & 0 & 1 & 6 & 9 & 36 & $54.55 \%$ \\
\hline Taiwan & 11 & 67 & 397 & 6 & 0 & 0 & 3 & 12 & 44 & $32.84 \%$ \\
\hline Malaysia & 10 & 42 & 300 & 7 & 0 & 0 & 3 & 7 & 28 & $66.67 \%$ \\
\hline England & 8 & 26 & 177 & 7 & 0 & 0 & 2 & 5 & 14 & $76.92 \%$ \\
\hline Australia & 8 & 24 & 182 & 8 & 0 & 1 & 1 & 3 & 12 & $95.83 \%$ \\
\hline Portugal & 8 & 24 & 151 & 6 & 0 & 0 & 0 & 7 & 15 & $37.50 \%$ \\
\hline
\end{tabular}

A special indicator considered in this Table is CR (cooperation rate), it illustrates the degree of cooperation between different countries. Considering the individual, Australia owns the highest rate of $95.83 \%$ while Taiwan gets the lowest one of $32.84 \%$.

\subsection{Top productive institutions}

Table 5 analyzes the top 11 productive institutions during 2008-2018. It contains some significant indicators including h-index, TP, TC, TC/TP, citation threshold and CR. The institutions are in a descending order decided by the TP. Among these 11 institutions, Lithuania and USA have two institutions respectively. The first institution in the ranking is VGTU with a total of 171 studies published in the JCEM, where 23 of these studies have received at least 23 citations. Furthermore, it contains more than four times TP as of the second one, Kaunas University of Technology. Focus on threshold, four papers gain a citation one hundred and more. They belong to the VGTU. In terms of $\mathrm{CR}$, Yonsei University from South Korea ranked first with $100 \%$ cooperation rate.

\subsection{The most productive and influential authors}

Table 6 presents the 13 most productive authors in the JCEM journal, with a minimum publication of eight papers. M. J. K. Skibniewski from University of Maryland, USA leads the rank in TP. Z. Turskis from VGTU, Lithuania leads the list in TC, and E. K. Zavadskas, also from VGTU, leads the list in TC/TP. We also found that although China, Poland and South Korea are highly productive countries, there are no prolific authors from these countries.

According to the number of publications by the first author (FTP), M. Y. Cheng from National Taiwan University of Science and Technology, Taiwan ranked the first position, followed by R. Maciulaitis from VGTU, Lithuania with 9 publications. In terms of the number of publications by the corresponding authors (CTP), Z. Kala from Brno University of Technology, Czech Republic leaded the list, and H. P. Tserng from National Taiwan University, Taiwan ranked the second position. 
Table 5. Top 20 productive institutions during 2008-2018

\begin{tabular}{|c|c|c|c|c|c|c|c|c|c|c|c|c|}
\hline No & Institution name & $\begin{array}{l}\text { Country/ } \\
\text { Territory }\end{array}$ & $\mathrm{TP}$ & TC & $\mathrm{TC} / \mathrm{TP}$ & h-index & $>100$ & $>50$ & $>20$ & $>10$ & $>1$ & CR \\
\hline 1 & $\begin{array}{l}\text { Vilnius Gediminas } \\
\text { Technical University }\end{array}$ & Lithuania & 171 & 2127 & 12 & 23 & 3 & 2 & 24 & 34 & 86 & $60.23 \%$ \\
\hline 2 & $\begin{array}{l}\text { Kaunas University } \\
\text { of Technology }\end{array}$ & Lithuania & 36 & 262 & 7 & 10 & 0 & 0 & 1 & 9 & 24 & $63.89 \%$ \\
\hline 3 & $\begin{array}{l}\text { National Taiwan } \\
\text { University of Science } \\
\text { Technology }\end{array}$ & Taiwan & 21 & 132 & 6 & 6 & 0 & 0 & 2 & 1 & 17 & $66.67 \%$ \\
\hline 4 & $\begin{array}{l}\text { Wroclaw University } \\
\text { of Science Technology }\end{array}$ & Poland & 21 & 180 & 9 & 9 & 0 & 0 & 2 & 6 & 13 & $19.05 \%$ \\
\hline 5 & Islamic Azad University & Iran & 19 & 170 & 9 & 8 & 0 & 0 & 2 & 4 & 11 & $84.21 \%$ \\
\hline 6 & Universiti Malaya & Malaysia & 17 & 154 & 9 & 7 & 0 & 0 & 2 & 2 & 11 & $64.71 \%$ \\
\hline 7 & $\begin{array}{l}\text { University System } \\
\text { of Maryland }\end{array}$ & USA & 17 & 217 & 13 & 9 & 0 & 0 & 5 & 3 & 9 & $88.24 \%$ \\
\hline 8 & $\begin{array}{l}\text { University of Maryland } \\
\text { College Park }\end{array}$ & USA & 16 & 215 & 13 & 9 & 0 & 0 & 5 & 3 & 8 & $87.50 \%$ \\
\hline 9 & Yonsei University & South Korea & 14 & 65 & 5 & 4 & 0 & 0 & 0 & 2 & 10 & $100.00 \%$ \\
\hline 10 & $\begin{array}{l}\text { Brno University } \\
\text { of Technology }\end{array}$ & $\begin{array}{l}\text { Czech } \\
\text { Republic }\end{array}$ & 13 & 275 & 21 & 7 & 0 & 2 & 5 & 0 & 3 & $38.46 \%$ \\
\hline 11 & $\begin{array}{l}\text { Tarbiat Modares } \\
\text { University }\end{array}$ & Iran & 13 & 92 & 7 & 5 & 0 & 0 & 1 & 2 & 8 & $76.92 \%$ \\
\hline
\end{tabular}

Table 6. The most productive and influential authors of the JCEM publications

\begin{tabular}{|c|c|c|c|c|c|c|c|c|c|c|c|c|}
\hline Rank & Name & Institution & $\begin{array}{l}\text { Country/ } \\
\text { Territory }\end{array}$ & $\mathrm{TP}$ & TC & $\mathrm{TC} / \mathrm{TP}$ & FTP & CTP & $\mathrm{H}$ & $\geq 50$ & $\geq 20$ & $\geq 10$ \\
\hline 1 & Skibniewski, M. J. K. & University of Maryland & USA & 18 & 256 & 14 & 2 & 3 & 10 & 0 & 6 & 4 \\
\hline 2 & Turskis, Z. & VGTU & Lithuania & 15 & 625 & 42 & 2 & 5 & 8 & 3 & 3 & 2 \\
\hline 3 & Cheng, M. Y. & $\begin{array}{l}\text { National Taiwan } \\
\text { University of Science } \\
\text { and Technology }\end{array}$ & Taiwan & 12 & 69 & 6 & 12 & 1 & 5 & 0 & 1 & 1 \\
\hline 4 & Maciulaitis, $\mathrm{R}$. & VGTU & Lithuania & 12 & 54 & 5 & 9 & 5 & 4 & 0 & 0 & 2 \\
\hline 5 & Sivilevicius, $\mathrm{H}$. & VGTU & Lithuania & 12 & 108 & 9 & 3 & 3 & 7 & 0 & 1 & 5 \\
\hline 6 & Ustinovichius, L. & VGTU & Lithuania & 11 & 86 & 8 & 3 & 2 & 5 & 0 & 1 & 2 \\
\hline 7 & Kala, Z. & $\begin{array}{l}\text { Brno University } \\
\text { of Technology }\end{array}$ & $\begin{array}{l}\text { Czech } \\
\text { Republic }\end{array}$ & 9 & 269 & 30 & 7 & 8 & 7 & 2 & 5 & 0 \\
\hline 8 & Zavadskas, E. K. & VGTU & Lithuania & 9 & 613 & 68 & 3 & 4 & 8 & 3 & 4 & 1 \\
\hline 9 & Adeli, H. & Ohio State University & USA & 8 & 71 & 9 & 0 & 6 & 5 & 0 & 1 & 2 \\
\hline 10 & Daniunas, A. & VGTU & Lithuania & 8 & 59 & 7 & 2 & 1 & 6 & 0 & 0 & 2 \\
\hline 11 & Kavussi, A. & $\begin{array}{l}\text { Tarbiat Modares } \\
\text { University }\end{array}$ & Iran & 8 & 45 & 6 & 4 & 4 & 4 & 0 & 0 & 2 \\
\hline 12 & Stankevicius, V. & $\begin{array}{l}\text { Kaunas University } \\
\text { of Technology }\end{array}$ & Lithuania & 8 & 32 & 4 & 2 & 0 & 4 & 0 & 0 & 0 \\
\hline 13 & Tserng, H. P. & $\begin{array}{l}\text { National Taiwan } \\
\text { University }\end{array}$ & Taiwan & 8 & 52 & 7 & 6 & 7 & 5 & 0 & 0 & 2 \\
\hline
\end{tabular}




\section{Networks of cooperation and research topics}

In the following, the cooperation networks at the country/territory level is investigated and shown in Figure 1 (a threshold of 10). It can be seen that the cooperation network between countries /territories is very dense. In addition, South Korea, China and Australia have strong cooperative relations with the USA. The partnership between Australia and China, Lithuania and Poland, Lithuania and Iran are also very strong.

The largest cooperation network at the institution level of the JCEM journal is presented in Figure 2. It should be noted that the size of the node indicates the frequency of cooperation with other institutions, rather than the publication number of this institution. In this network, VGTU cooperates most with other institutions. In addition, Kaunas University of Technology Lithuania, Wrocław University of Science and Technology from Poland, National Taiwan University of Science and Technology from Taiwan, Islamic Azad University from Iran and University of Malaya from Malaysia occupy important positions in the cooperative network. In addition, the lines in the figure indicate the collaboration between the institutions. The color and thickness of the connections reflect the cooperation model in the JCEM journal.

We investigate the frequently used keywords in journal papers in order to identify the main research topics of the JCEM journal. It should be pointed out that here we only analyze the keywords provided by the author.

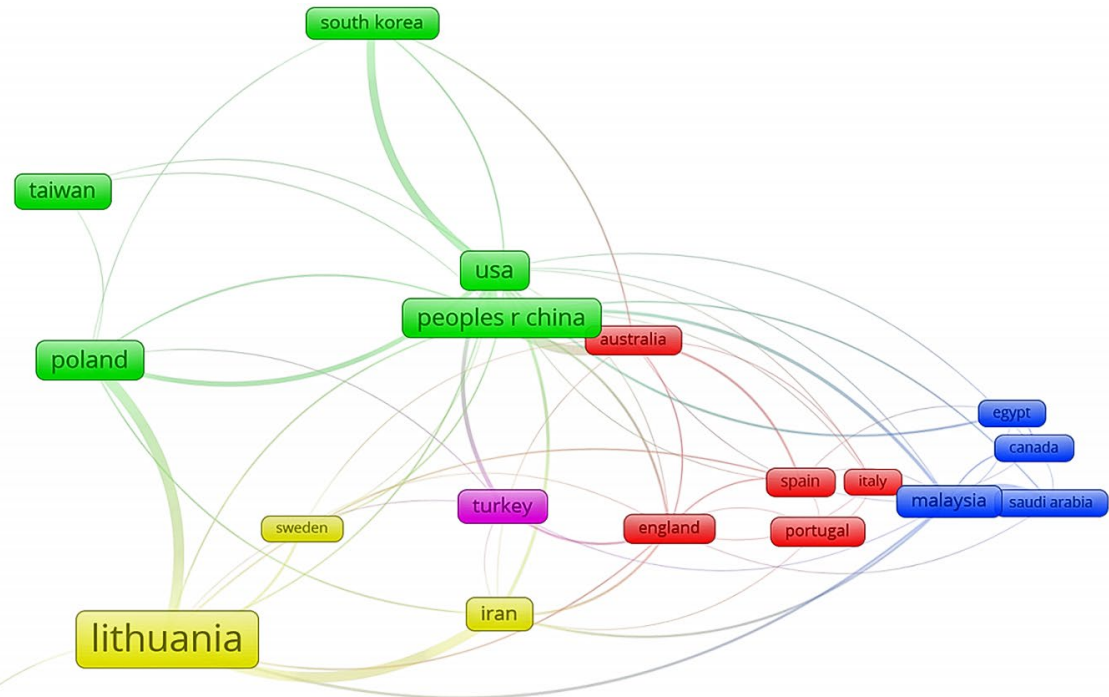

Figure 1. Cooperation networks at the country/territory level

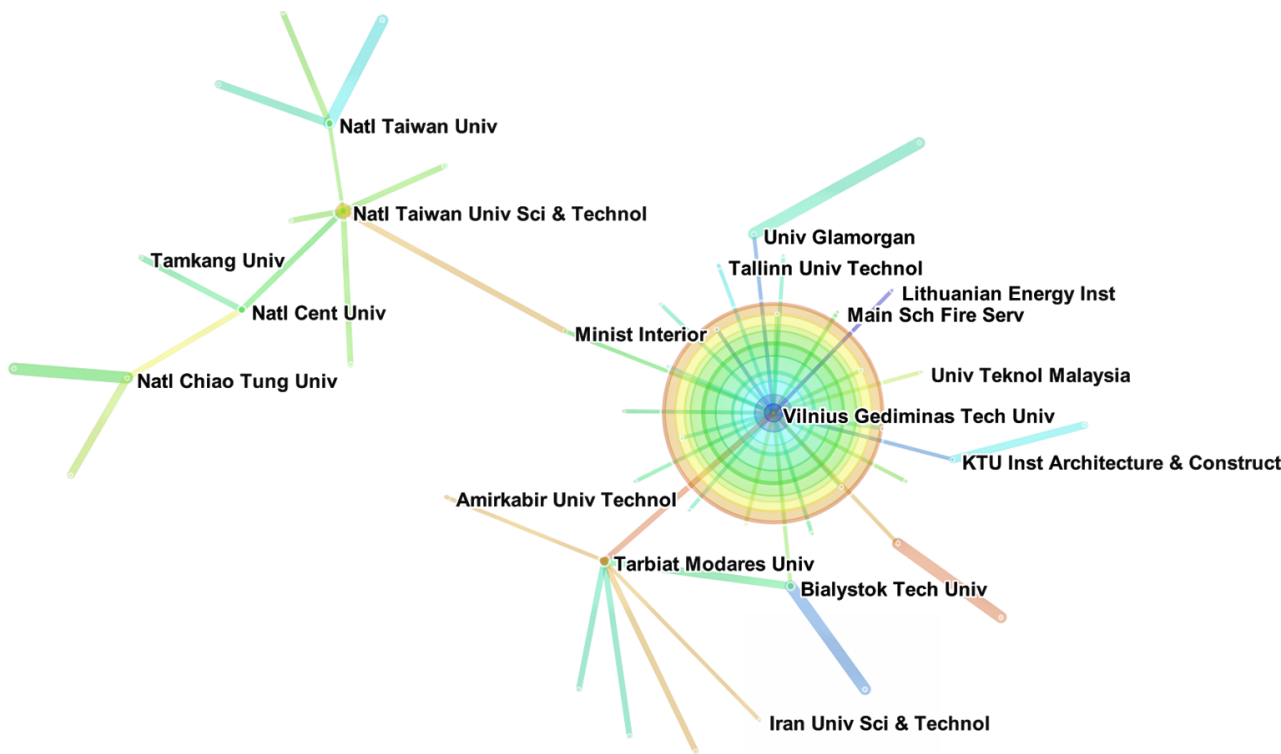

Figure 2. The biggest cooperation network at the institution level 


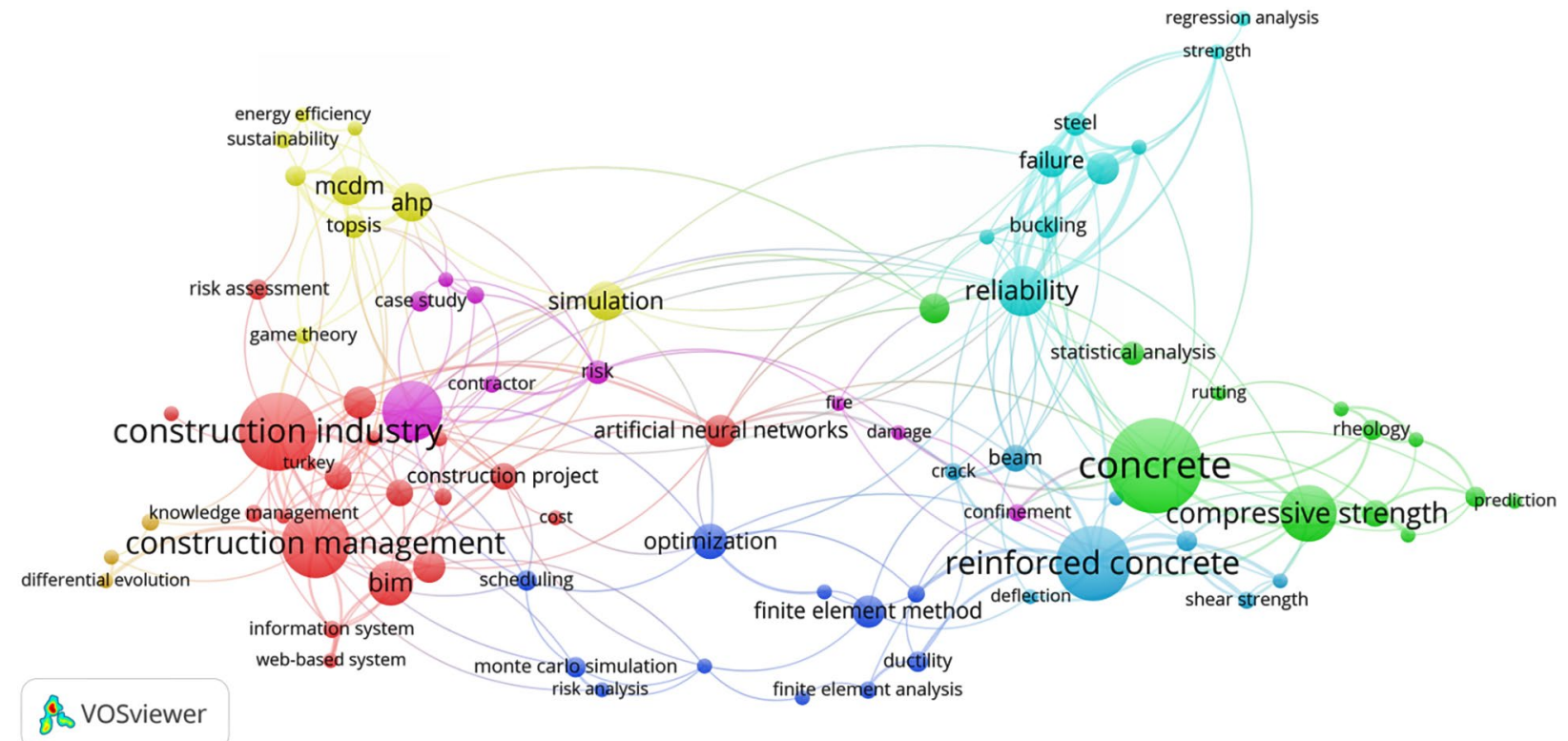

Figure 3. Co-occurrence of author keywords of the JCEM publications

The map presents those keywords that appear frequently in the JCEM publications and the lines in the network indicate co-occurrence of the keywords in the same paper. Figure 3 shows the co-occurrence network of the frequently appeared author keywords (a threshold of 5). The word "concrete" is the most frequently used author keyword in the journal. Some other keywords are construction industry, construction management, reinforced concrete and compressive strength, also MCDM, simulation and optimization. The above keywords represent the main topics of the journal. In addition, there are some thick lines in the network, for example, the connections between reliability and steel, reliability and failure, construction management and differential evolution, indicated that these keywords appear frequently in the same JCEM publication.

\section{Concluding remarks}

Since the first issue of the JCEM journal published in 1995, it has contributed hundreds of articles by 2018. It plays an important role for the accumulation and dissemination of knowledge in the field of engineering. In this paper, we mainly analyzed all the papers of the JCEM journal from 2008 to 2018 by using bibliometric methods and knowledge map tools, and revealed the knowledge structure and development process of this journal.

$52.86 \%$ of the JCEM papers were equal to or less than 10 pages and there was clear evidence of an increase in the average number of pages. The number of references of the JCEM papers concentrated on 21-40, which accounted $52.62 \%$ of the total. The share of papers with more than 30 references increased significantly. The most popular pattern of co-authorship was 2 or 3 authors. Lithuania was the most productive country with more than twice the number of papers of Poland, which is in the second place. Within the top 11 productive institutions, Lithuania and USA have two institutions respectively. South Korea, China and Australia have strong cooperative relations with the USA. The partnership between Australia and China, Lithuania and Poland, Lithuania and Iran are also very strong.

VGTU cooperated most with other institutions. In addition, Kaunas University of Technology Lithuania, Wroclaw University of Science and Technology from Poland, National Taiwan University of Science and Technology from Taiwan, Islamic Azad University from Iran and University of Malaya from Malaysia occupied important positions in the cooperative network. "Concrete" is the most frequently used author keyword in the JCEM journal. Some other keywords are construction industry, construction management, reinforced concrete, compressive strength, MCDM, simulation and optimization.

This paper made a bibliometric analysis of all publications of the JCEM journal and it hopes to contribute to the field of engineering. In the future, we will analyze the research hotspots and their changes of the journal from different perspectives in combination with the method of text mining.

\section{References}

Borgman, C. L., \& Furner, J. (2002). Scholarly communication and bibliometrics. Annual Review of Information Science and Technology, 36(1), 2-72. https://doi.org/10.1002/aris.1440360102

Cui, T., \& Zhang, J. (2018). Bibliometric and review of the research on circular economy through the evolution of Chinese public policy. Scientometrics, 116(2), 1013-1037. https://doi.org/10.1007/s11192-018-2782-y

Ertz, M., \& Leblanc-Proulx, S. (2018). Sustainability in the collaborative economy: A bibliometric analysis reveals emerging interest. Journal of Cleaner Production, 196, 1073-1085. https://doi.org/10.1016/j.jclepro.2018.06.095 
Hache, E., \& Palle, A. (2019). Renewable energy source integration into power networks, research trends and policy implications: A bibliometric and research actors survey analysis. Energy Policy, 124, 23-35. https://doi.org/10.1016/j.enpol.2018.09.036

Hao, T., Chen, X., Li, G., \& Yan, J. (2018). A bibliometric analysis of text mining in medical research. Soft Computing, 22(23), 7875-7892. https://doi.org/10.1007/s00500-018-3511-4

He, X., Wu, Y., Yu, D., \& Merigó, J. M. (2017). Exploring the ordered weighted averaging operator knowledge domain: a bibliometric analysis. International Journal of Intelligent Systems, 32(11), 1151-1166. https://doi.org/10.1002/int.21894

Köseoglu, M. A., Okumus, F., Putra, E. D., Yildiz, M., \& Dogan, I. C. (2018). Authorship trends, collaboration patterns, and coauthorship networks in lodging studies (1990-2016). Journal of Hospitality Marketing \& Management, 27(5), 561-582. https://doi.org/10.1080/19368623.2018.1399192

Laengle, S., Merigó, J. M., Miranda, J., Słowiński, R., Bomze, I., Borgonovo, E., Dysone, R.G., Oliveira, J.F. \& Teunter, R. (2017). Forty years of the European Journal of Operational Research: A bibliometric overview. European Journal of Operational Research, 262(3), 803-816.

https://doi.org/10.1016/j.ejor.2017.04.027

Maditati, D. R., Munim, Z. H., Schramm, H. J., \& Kummer, S. (2018). A review of green supply chain management: From bibliometric analysis to a conceptual framework and future research directions. Resources, Conservation and Recycling, 139, 150-162. https://doi.org/10.1016/j.resconrec.2018.08.004

Martínez-López, F. J., Merigó, J. M., Valenzuela-Fernández, L., \& Nicolás, C. (2018). Fifty years of the European Journal of Marketing: a bibliometric analysis. European Journal of Marketing, 52(1/2), 439-468.

https://doi.org/10.1108/ejm-11-2017-0853

Ortega, J. L. (2019). Exploratory analysis of Publons metrics and their relationship with bibliometric and altmetric impact. Aslib Journal of Information Management, 71(1), 124-136. https://doi.org/10.1108/ajim-06-2018-0153

Pritchard, A. (1969). Statistical bibliography or bibliometrics. Journal of Documentation, 25(4), 348-349.

Silva, F. S., Schulz, P. A., \& Noyons, E. C. (2019). Co-authorship networks and research impact in large research facilities: benchmarking internal reports and bibliometric databases. Scientometrics, 118(1), 93-108.

https://doi.org/10.1007/s11192-018-2967-4
Tur-Porcar, A., Mas-Tur, A., Merigó, J. M., Roig-Tierno, N., \& Watt, J. (2018). A bibliometric history of the Journal of Psychology between 1936 and 2015. The Journal of Psychology, 152(4), 199-225.

https://doi.org/10.1080/00223980.2018.1440516

Wang, W., Laengle, S., Merigó, J. M., Yu, D., Herrera-Viedma, E., Cobo, M. J., \& Bouchon-Meunier, B. (2018). A bibliometric analysis of the first twenty-five years of the International Journal of Uncertainty, Fuzziness and Knowledge-Based Systems. International Journal of Uncertainty, Fuzziness and Knowledge-Based Systems, 26(02), 169-193.

https://doi.org/10.1142/s0218488518500095

White, H. D. (2018). Pennants for Garfield: bibliometrics and document retrieval. Scientometrics, 114(2), 757-778. https://doi.org/10.1007/s11192-017-2610-9

Wu, F., Geng, Y., Tian, X., Zhong, S., Wu, W., Yu, S., \& Xiao, S. (2018). Responding climate change: A bibliometric review on urban environmental governance. Journal of Cleaner Production, 204, 344-354. https://doi.org/10.1016/j.jclepro.2018.09.067

Yu, D. J., \& Xu, C. (2017). Mapping research on carbon emissions trading: a co-citation analysis. Renewable and Sustainable Energy Reviews, 74, 1314-1322.

https://doi.org/10.1016/j.rser.2016.11.144

Yu, D. J., Xu, Z. S., \& Fujita, H. (2019). Bibliometric analysis on the evolution of applied intelligence. Applied Intelligence, 49(2), 449-462. https://doi.org/10.1007/s10489-018-1278-Z

Yu, D. J., Xu, Z. S., \& Wang, W. (2018). Bibliometric analysis of fuzzy theory research in China: A 30-year perspective. Knowledge-Based Systems, 141, 188-199. https://doi.org/10.1016/j.knosys.2017.11.018

Yu, D. J., Xu, Z. S., Kao, Y., \& Lin, C. T. (2018). The structure and citation landscape of IEEE Transactions on Fuzzy Systems (1994-2015). IEEE Transactions on Fuzzy Systems, 26(2), 430-442. https://doi.org/10.1109/tfuzz.2017.2672732

Yu, D. J., Xu, Z. S., Pedrycz, W., \& Wang, W. (2017). Information Sciences 1968-2016: a retrospective analysis with text mining and bibliometric. Information Sciences, 418, 619-634. https://doi.org/10.1016/j.ins.2017.08.031 